STUDI

FRANCESI

\section{Studi Francesi}

Rivista quadrimestrale fondata da Franco Simone

190 (LXIV | I) | 2020

Varia - fasc. I - gennaio-aprile 2020

\title{
La Vie de Saint Alexis en ancien français, édition, introduction, notes et index de M. PERUGI
}

\section{Walter Meliga}

\section{OpenEdition}

\section{Journals}

\section{Edizione digitale}

URL: https://journals.openedition.org/studifrancesi/22257

DOI: 10.4000/studifrancesi.22257

ISSN: 2421-5856

\section{Editore}

Rosenberg \& Sellier

\section{Edizione cartacea}

Data di pubblicazione: 1 avril 2020

Paginazione: 148

ISSN: 0039-2944

Notizia bibliografica digitale

Walter Meliga, «La Vie de Saint Alexis en ancien français, édition, introduction, notes et index de $\mathrm{M}$ PERUGI», Studi Francesi [Online], 190 (LXIV | I) | 2020, online dal 01 avril 2020, consultato il 03 août 2021. URL: http://journals.openedition.org/studifrancesi/22257 ; DOI: https://doi.org/10.4000/studifrancesi. 22257

Questo documento è stato generato automaticamente il 3 août 2021.

\section{(†) $\odot$

Studi Francesi è distribuita con Licenza Creative Commons Attribuzione - Non commerciale - Non opere derivate 4.0 Internazionale. 


\title{
La Vie de Saint Alexis en ancien français, édition, introduction, notes et index de M. PERUGI
}

\author{
Walter Meliga
}

\section{NOTIZIA}

La Vie de Saint Alexis en ancien français, édition, introduction, notes et index de M. PERUGI, Traduction en français moderne de V. FASSEUR et M. PERUGI, Genève, Droz, 2017, «Texte courant» 2, $121 \mathrm{pp}$.

1 L'edizione riprende con qualche piccolo ritocco quella già presente nel grande studio che lo stesso Perugi ha pubblicato nel 2014 sull'origine della leggenda di sant'Alessio e della Vie antico-francese (Saint Alexis, genèse de sa légende et de la "Vie" française. Révisions et nouvelles propositions accompagnées d'une nouvelle édition critique de la "Vie", Genève, Droz, 2014) e a quella il curatore rimanda per la giustificazione del testo, che ne mantiene anche lo stile tipografico, con variazioni di corpo e di carattere peraltro non ben chiarite nella breve «Note de l'éditeur» (pp. XLV-XLVI). Dallo stesso studio del 2014 discende anche l'introduzione (pp. vII-XXXviII), che risulta però un po' difficile per un lettore non informato sulla complessa vicenda che ha portato alla composizione del Saint Alexis - testo agiografico com'è noto straordinario, certamente il più bello del Medioevo - e che forse andava estesa un po' oltre la trentina di pagine che la compongono (lo studio di partenza ne conta 799!) - proprio in ragione dell'importanza del poema.

2 La traduzione è intesa «reconduire le lecteur d'aujourd'hui vers le texte ancien», cercando di «rendre avec autant d'exactitude que possible la lettre du texte» (p. XLVII), ma il risultato non sembra andare oltre un'onesta resa naturalizzante, qualche volta anche riduttiva dello spessore semantico delle forme antiche, spesso non esplicitato nelle note. L'obiettivo dichiarato di mantenere «la vivacité» (p. xuIx) dell'opera in 
definitiva non è raggiunto, l'intensità e il fulgore della quale restando sostanzialmente ridimensionati dall'intenzione di corrispondere alle «habitudes d'un lecteur contemporain». Chiude il libro un glossario-concordanza, utile anche per rapide ricerche all'interno del testo, ma che l'assenza dell'apparato critico farà consultare con prudenza. 